\title{
CULTURAL QUARTERS AS A MEANS OF ENHANCING THE CREATIVE CAPACITY OF POLISH CITIES? SOME EVIDENCE FROM CRACOW
}

\author{
MONIKa MurZYN-KupISZ \\ Cracow University of Economics \\ Manuscript received: January 2, 2012 \\ Revised version: 12 October 2012
}

\begin{abstract}
MurzYn-Kupisz M., 2012. Cultural quarters as a means of enhancing the creative capacity of Polish cities? Some evidence from Cracow. Quaestiones Geographicae 31(4), Bogucki Wydawnictwo Naukowe, Poznań, pp. 63-76. 4 tables. DOI 10.2478/v10117-012-0036-2, ISSN 0137-477X.

AвSTRACT. Culture-oriented activities conducted by diverse actors in selected urban areas may lead to the formation of unique quarters of production and consumption of cultural goods and services which function both as creative hubs and leisure spaces. Such cultural quarters may develop spontaneously or as a result of official designation and major public investment. Referring to the debate on cultural quarters in Western Europe, this article aims to examine the issue of the spatial concentration of cultural and creative activities within a selected large city in Poland. The author analyses recent transformations of two historic quarters in Cracow (Kazimierz and Podgórze) and considers the extent to which both areas can be regarded as successful cultural quarters. She describes their emergence and the changes observed in them in terms of groupings, character and number of creative-sector firms established there, pondering whether their role is limited to a function as centres of commercial cultural entertainment and night-life consumption, or whether they indeed stimulate the development of a creative economy.
\end{abstract}

KEY WORDS: cultural quarters, creative industries, urban regeneration, Cracow

Monika Murzyn-Kupisz, Cracow University of Economics, ul. Rakowicka 27, 31-501 Cracow, Poland; e-mail: murzynm@ uek.krakow.pl

\section{Introduction}

The term 'cultural quarter' is usually applied to specialised functional areas in cities characterised by a concentration of cultural infrastructure and diverse activities linked with the production of cultural goods and the provision of cultural services (Montgomery 2003, Roodhouse 2010). Such quarters may benefit from having interesting, at times newly reinterpreted heritage sites and from being the location of a mix of contemporary cultural and creative endeavours.

Research into the creative sector focused on selected metropolitan areas has been undertaken by several researchers in Poland (e.g. Stryjakiewicz et al. 2007, Grochowski 2010, chapters in Musterd \& Murie 2010, Klasik 2011). Although many papers acknowledge the issue of local clusters of creative industries and activities, development problems facing cultural quarters are 
nonetheless more often examined with respect to cities in Western Europe (Bianchini \& Parkinson 1993, Bell \& Jayne 2004) than those in Central and Eastern Europe, and more specifically Poland. Hence, while referring to the broader discussion on cultural quarters, this article aims to illustrate the issue of the location and functioning of creative activities at the local level of specific quarters within a selected metropolitan centre in Poland. In her review of the literature on cultural quarters and a subsequent analysis of the transformation of two historic quarters in Cracow (Kazimierz and Old Podgórze), the author's objective is to show the extent to which these new areas of concentration of the production of cultural goods and the supply of cultural services may indeed be regarded as cultural quarters. She discusses their emergence and changes observed in them in terms of groupings, the character and number of firms and institutions in the creative sector.

\section{Desired features of a cultural quarter}

Definitions of the unique features of cultural quarters often emphasise the diversity of uses of the urban space in such areas in terms of their functions (sites of cultural production and consumption) and usage (places of work, leisure, residence, essential services) (e.g. Moss 2002). They usually feature the full spectrum of times of activity (a 24-hour economy) and "a mix of indoor and outdoor spaces attractive for gazing, ambling, sitting and observing". They may be focused on a specific cultural sector (e.g. performing arts, fine arts and galleries). Another important feature of cultural quarters is the coexistence of many individuals and firms forming complex "clusters of activities" and "networks embedded in a particular place" (Roodhouse 2010: 24, O'Connor 2004). Such networks do not necessarily have an economic character, as some quarters are created by a community of artists and creative professionals for whom the possibility of interaction with other creative individuals is most important. Such links may also weaken with time as a given generation of creators matures and diversifies, some of them gradually moving out of the quarter, while the area itself evolves from the initial spontaneous to a mature phase. Similarly, in terms of unique features and success factors of cultural quarters, Montgomery (2003) underlines three sets of desired characteristics: activities (of an economic, social and cultural character), built form, and meaning. Among the functional indicators of a "well functioning" cultural quarter are: diversity of land uses; existence of various cultural venues; supplementation of large-scale public infrastructure with smaller, more modest spaces; quantity and quality of cultural events; organisation of artistic projects and festivals in the area; visibility of artistic endeavours in its public spaces; presence of SMEs, especially creativesector firms; availability of workspaces for artists and low-cost cultural producers; complementary daytime and evening uses, including the presence of an evening economy; and location of arts development agencies and companies as well as arts and media training and education institutions. Next, cultural quarters should provide well designed, inspiring, legible urban spaces: quality public spaces, a varied, adaptable building stock, and active street frontages, appreciated by both those who live and work there and those who visit them as cultural creators, consumers or simply flâneurs. The third important aspect of cultural quarters is their symbolic meaning: whether a given area has a distinct identity and set of imagery and exudes a sense of history and progress that contributes to its unique image, and whether it has developed sought-after meeting spaces.

The discussion of cultural quarters and the benefits of their existence also addresses two further important issues: the mechanisms of their emergence and their development paths, and the character of the cultural production and consumption which takes place in them. Some quarters emerge 'organically' following the spontaneous evolution of the urban space and the creation of clusters of culture-related activities. Others are established pursuant to decisions by public authorities or (less often) major private investors (Bell \& Jayne 2004). Selected, centrally located, prestigious inner-city areas in historic metropolises have naturally developed and retained for decades features of cultural quarters. Most important historic cultural institutions, the organisations supporting them, promotional and educational institutions, and related creative-sector firms tend to 
be located in such city-centre areas. Culture is an important aspect of the identity and image of such areas, which leads to a specific slant on the perception of the entire city. The second subtype of 'naturally born' cultural quarters are often less prestigious, dilapidated and degraded, but culturally interesting and well situated (e.g. on the fringe of the city core) inner-city or postindustrial areas. These emerge as the result of many uncoordinated decisions and activities by artists and small firms. At some point in time representatives of the creative sector spontaneously start to settle or conduct their activities there, finding them to be attractive and unique in some way. It is in such areas that often avantgarde, low-budget cultural activities requiring inspiring but inexpensive spaces are initiated. If they become better known, however, and reach a certain 'critical stage' in terms of cultural production and attracting external customers, they start to be 'officially' perceived as bohemian. The new cultural image of a quarter can help to attract further firms in the cultural, tourism and entertainment sector and transform it into a tourist attraction, creating a self-reinforcing mechanism of development of its cultural and entertainment function. Such areas can function as informal 'do-it-yourself' cultural quarters for a longer period of time or be ephemeral groupings (Moss 2002). Their spontaneous creation can be followed by a gradual waning and disappearance of avant-garde activities from them. If they come to be regarded as artistic, they can experience gentrification and rising property prices, which causes the pioneering artists to leave and leads to a gradual weakening of their culture-inspiring role (Evans 2004).

The second major type of cultural quarters are areas designated as such by public authorities launching significant promotional activities or culture-related investments in the area. They most often come into existence following highvisibility initiatives by public authorities who see a need to introduce or develop and diversify the cultural function of a given area of a large city. The establishment of a cultural quarter is often part of a broader strategy of urban regeneration (Bianchini \& Parkinson 1993). The aim of such a designation may be not only to revitalise an area, but also to boost or alter completely the city's image, in part by broadening its cultural offer or introducing new elements into it. Yet another motive may be to rediscover, recreate or strengthen the existing artistic, creative and craft traditions. In recent decades, for instance, projects have been undertaken in many post-industrial cities in Great Britain and the Ruhr region in Germany designed to 'rebrand' them with a new, dynamic image founded on culture in conjunction with new culture-based economic activities (e.g. the Cultural Industries Quarter in Sheffield, Moss 2002), or to change their image by enhancing the existing but weakened local creative-sector traditions (e.g. the Jewellery Quarter in Birmingham, de Propris \& Wei 2009). The MuseumsQuartier in Vienna, in turn, was conceived as a way of updating and broadening the city's cultural image to include contemporary culture. The intention here was not to destroy the former image, but rather to diversify the cultural image of the metropolis (Roodhouse \& Mokre 2004). Cultural quarters emerging today within metropolitan centres can also be the result of a combination of location decisions and developments (for a complementary typology see Miles 2004).

A parallel development issue is that of the various functions fulfilled by a cultural quarter and the proportions between them in terms of cultural creation and consumption. Should such quarters be primarily spaces of leisure and entertainment for residents and visitors, or act as creative hubs and spaces of cultural production? Sacco (2010) distinguishes two main functional models of cultural quarters. The "vertically integrated, entertainment-driven model" is typical of quarters with a leisure specialisation whose infrastructure, cultural services and ambiance are mostly intended, whether by design or evolution, to attract non-local customers. Their success is based on their ability to generate profit. Their offer tends to change slowly, while their culturecreating role within the city has a tendency to stagnate or gradually weaken, especially if their specialisation, e.g. a focus on night life, causes mono-functional, entertainment-oriented development. The second functional type is defined as a "horizontally integrated, production-driven model". Such quarters, referred to as "creative hubs", specialize in cultural production. Complex links and interdependencies develop be- 
tween the firms operating within them, while the mutual proximity of specialised cultural, educational, service and production infrastructure (e.g. recording studios, printing houses, editorial offices) is an important location factor. In such quarters culture is not merely a leisure option, but a constitutive part of everyday life and its quality from the perspective of residents, people employed in the quarter, and regular visitors to it. This type is considered to have better chances of maintaining a cultural character and dynamics in the long run.

Though in the recent years public authorities have tended to give more support to consumption-oriented developments (Evans 2004), it seems that properly functioning cultural quarters should be home to entities offering both cultural consumption and production, a mixture of publicly supported and private activities, non-profit and commercial endeavours, and production and delivery of both élite and popular or mass-culture products (Montgomery 2003). Neither complete domination of the production function (a cultural quarter treated as synonymous with a cultural industries quarter) nor a sole focus on leisure and entertainment are desired. A cultural quarter should thus be a place where creative and artistic achievements and products are showcased and consumed, but at the same time it should also be a locus of their creation, and a cradle of new ideas and artistic experiments.

\section{The case study and its methodology}

As one of the best known historic cities in Poland, famous for its architecture, ambiance and cultural traditions, Cracow has for centuries been considered the cultural capital of Poland, and at present, if no longer the leading, nevertheless still one of the country's most important cultural centres. As it is also one of the most important metropolitan cities in Poland, and has seen a rapid social and economic transformation in the post-socialist period, it seems particularly well suited as a case study of the presence and recent evolution of the cultural function in the urban space of a major urban centre in Poland. As in the case of other historic European metropolises, the historic urban core - the Old Town within the perimeter delineated by the former medieval city walls - has traditionally been the focus of cultural and creative activities. In recent decades, however, its position has been increasingly challenged not only by the dispersion of some creative endeavours into other areas of the city, but also by the emergence of significant new areas of concentration of cultural activity, particularly south of the historic Old Town. Cultural activities have visibly expanded and intensified in two districts of the city that were once independent towns: Kazimierz and Stare (Old) Podgórze. In the strategic documents of the city (e.g. Big Städtebau GmbH 2008) both districts are often mentioned as problem areas in need of urban regeneration, but also as centrally located inner-city zones which are potentially important hubs for the city's economic, social and cultural development. However, is their role limited to being areas of commercial cultural consumption linked with entertainment and night life, or are they indeed places stimulating creativity, in terms of both cultural activity and, more broadly speaking, provision of support and inspiration for the development of the creative economy, thus influencing the creative potential of the city? What were the mechanisms of their emergence, and do they display typical features of cultural quarters as described in their Western European counterparts?

In order to understand the functioning of the two quarters and the development of their cultural function, the author reviewed the existing literature on their development since 1989, analysed municipal documents (e.g. master plans, urban regeneration programmes, development strategies) and web sites on Cracow and the quarters themselves, and searched for mentions of the two quarters in the local and national press over the past two decades. A crucial pendant to this desk-top research was field work, which involved mapping, participant observation, and interviews with selected local actors conducted by the author in both quarters over the period 20032011. In particular, detailed primary data on the creative sector in both quarters was obtained during mapping observation by the author in the third quarter of 2011 and, where possible, compared with earlier data (e.g. data on the functions of Kazimierz in 2004). 


\section{Multicultural Kazimierz as a cultural quarter}

\subsection{Main characteristics of the quarter}

The quarter of Kazimierz ${ }^{1}$ is a historic district comprising valuable Christian monuments, a unique Jewish heritage of international significance, a post-industrial area incorporating a former gas works, power station and tram depot, and tenement houses dating mainly from the $19^{\text {th }}$ and early $20^{\text {th }}$ centuries. For decades following the Second World War, the quarter was perceived as one of the most degraded districts of Cracow. Since 1989 it has seen profound, dynamic changes of a morphological, economic, functional and social nature (Murzyn 2006).

\subsection{Development of cultural and creative activities in the quarter after 1989}

The urban regeneration process observed in Kazimierz has to a large extent been linked to the development of its cultural, tourism and entertainment functions, which has also had a great impact on its new image and branding as the Cracow 'Soho' or 'Montmartre'. Such changes in perception have chiefly resulted from the activities of two dynamic non-governmental institutions (the Centre for Jewish Culture and the Jewish Culture Festival Society) ${ }^{2}$ promoting the quarter and organising many cultural events focused on Jewish culture as an important part of the quarter's heritage. They were also enhanced, however, by a large number of small, private initiatives, mainly the activities of artistic cafés and restaurants. Initially those were mostly concerts of Jewish music, but in time their programme diversified and broadened. ${ }^{3}$ Since the late $1990 \mathrm{~s} \mathrm{Ka-}$

1 Once an autonomous town south of Cracow, then a district of Cracow, and at present part of the larger District I - Cracow Old Town.

2 The Jewish Culture Festival was launched in 1988. For the last few years the headquarters of the association which organises it has been located in Kazimierz. It also runs a year-round artistic café in the quarter. The Centre for Jewish Culture has operated since 1993 in a former Jewish prayer house in Kazimierz.

3 Such as Alchemia (Alchemy) in New Square, Drukarnia (The Printing House) until its relocation to zimierz has also started to play a significant role on the city's map as a place where public lectures, presentations, artistic workshops, alternative film screenings and book promotions are held. At the same time it has become an important cluster of antique and contemporary art galleries and other similar institutions, as well as a venue for numerous open-air cultural events. Although less numerous, the private theatre initiatives present in the quarter should also be mentioned, such as the El-Jot Theatre, but most of all its avant-garde theatres: the Łaźnia (Bath House) Theatre Association, which operated in Kazimierz in the period 1997-2003, and in recent years the Nowy (New) Theatre and the Barakah Theatre.

In conclusion, in Kazimierz the gradual development of the cultural offer has led to its transformation into an important area providing cultural goods and services, in terms of quantity and variety second only to the historic core of Cracow. Its cultural function has developed to a large extent spontaneously, thanks to the activities of diverse individual private actors. The unique ambiance of the quarter, its favourable location within the city and lower rental rates became magnets attracting artists and cultural activities (both profit and non-profit oriented). With time the advantages of grouping also became an important factor. The participation of local public cultural institutions in the development of Kazimierz as a cultural quarter was initially rather limited, although some of them benefited from the increased tourist traffic to it (the Jewish Museum in the Old Synagogue, the Ethnographic Museum). The only major public initiative of the 1990s was the establishment of the new Museum of Municipal Engineering in the historic tram depot (1998), though in its first years of existence the regeneration of this complex progressed very slowly.

Throughout the 1990s the cultural function of Kazimierz developed in symbiosis with its entertainment, catering and tourist functions. In time the latter three started to dominate in the quar-

Podgórze, Klezmer Hois, whose owners also run a publishing house, Austeria, and a specialised bookshop in Kazimierz, and Lokator (The Tenant), an avant-garde café functioning as a meeting and presentation venue for young writers, promoting contemporary literature and since 2011, on new premises, also operating as a publisher. 
ter (Table 1). Although in the past eight years the number of activities and firms which can be defined as creative has increased by a third (120 in 2003, 156 in 2011), they are less visible in the quarter, as its image is dominated by entertainment and catering establishments whose number rose by a half in the same period (in 2011 as many as 181 catering establishments existed in Kazimierz). If there was one cultural or creative firm in the quarter per catering establishment in 2003, by 2011 this figure had decreased to 0.86 . This shift in proportion was in many cases accompanied by a trivialisation of the cultural offer or relocation of some activities to less expensive districts less popular with tourists and party goers.

Though the number of publishing houses and editorial offices in Kazimierz has increased re- cently, these ventures are still mainly of a local character. Significant in Kazimierz is its 'specialisation' in bookshops focusing on Jewish culture and heritage (as many as three such shops). The increase in the number of artistic craft workshops can be linked with a recent fashion for handmade jewellery, which can be fleeting, but also with a continuation of the tradition of bookbinding, engraving and artistic frame making. Single, though not numerous, contemporary design firms (furniture and fashion) have also been established. A new trend is a significant increase in the number of private establishments offering all sorts of artistic workshops and courses, especially dance classes and workshops for children, following a rising fashion for such services. In 2011 there were as many as 15 small firms of this

Table 1. The creative sector in the historic quarters of Kazimierz and Podgórze.

\begin{tabular}{|c|c|c|c|}
\hline \multirow[b]{2}{*}{ Type of activity } & \multicolumn{3}{|c|}{ Number of establishments } \\
\hline & $\begin{array}{l}\text { Kazimierz } \\
2003\end{array}$ & $\begin{array}{l}\text { Kazimierz } \\
2011\end{array}$ & $\begin{array}{c}\text { Old } \\
\text { Podgórze } \\
2011\end{array}$ \\
\hline $\begin{array}{l}\text { Museums and museum branches, historic interiors open to general } \\
\text { public, art galleries }\end{array}$ & 26 & 29 & $9^{*}$ \\
\hline Antique shops (trading, renovation), monument conservation & 17 & 13 & 12 \\
\hline $\begin{array}{l}\text { Cultural institutions other than museums run by public authorities or } \\
\text { religious organisations (cultural centres and venues, library branches) }\end{array}$ & 6 & 7 & 5 \\
\hline Cultural associations and foundations & 1 & 6 & 3 \\
\hline $\begin{array}{l}\text { Private artistic venues, organisation of workshops, courses, ateliers, } \\
\text { hire of artistic venues }\end{array}$ & 1 & 15 & 5 \\
\hline Artistic, media, film, event and casting agencies & 4 & 5 & 3 \\
\hline TV and film production & 0 & 1 & 6 \\
\hline Musical instruments and equipment & 7 & 6 & 3 \\
\hline Theatre groups and venues & 3 & 3 & 3 \\
\hline Book publishers, editorial offices & 2 & 6 & 8 \\
\hline Printing houses and related services & 2 & 3 & 11 \\
\hline Books: retail and wholesale & 5 & 7 & 4 \\
\hline Architecture and interior design & 9 & 10 & 15 \\
\hline Other design & 0 & 5 & 9 \\
\hline Photo studios, retail of photo articles & 8 & 6 & 5 \\
\hline Artistic crafts & 13 & 20 & 14 \\
\hline Artistic schools and their branches & 1 & 1 & 8 \\
\hline Design and production of advertising and promotional materials & 4 & 3 & 13 \\
\hline $\begin{array}{l}\text { Translation services, foreign language instruction (other than that } \\
\text { offered by cultural centres) }\end{array}$ & 6 & 4 & 4 \\
\hline Other & 5 & 6 & 5 \\
\hline Total & 120 & 156 & 145 \\
\hline Catering (restaurants, cafés, pubs, bars, fast food establishments) & 118 & 181 & 41 \\
\hline $\begin{array}{l}\text { Number of establishments in creative sector per catering establish- } \\
\text { ment in quarter }\end{array}$ & 1.02 & 0.86 & 3.54 \\
\hline
\end{tabular}

* including one museum under construction

Source: own elaboration based on mapping observation conducted in the third quarter of 2011 and Murzyn (2006). 
type operating in Kazimierz. In turn, the number of outlets renovating and selling antiques has declined in the past few years.

\subsection{Challenges faced by Kazimierz as a cultural quarter}

In recent decades the quarter has seen practically no major public investment designed to make its public spaces more attractive as meeting points and sites of artistic creation. The only such investment - the pedestrian Bernatka Bridge between Kazimierz and Podgórze - was completed in 2010 and has so far mainly inspired a 'café revival' in the streets leading to it in both quarters (e.g. Mostowa Street in Kazimierz). Many historic tenement houses have been renovated. Most of them, however, have been adapted for new, noncreative commercial functions (hotels, banks, luxury apartments), and some of those projects have failed to accommodate the unique landscape qualities of the quarter. High real-estate and rental prices in Kazimierz make it increasingly difficult for artistic and creative professionals to live or work there. They are being pushed out of the quarter by activities with a higher value added, bringing in fast profits and intended for a mass tourist or student audience. A sad though excellent expression of this trend is the protests of the creative tenants, artists and residents of one of the longest buildings in Józefa Street ("the most artistic street in Kazimierz") against its planned conversion into a luxury hotel, underway since the second half of 2011 (Maziarek \& Hajok 2011). Some of the catering and retail establishments in the quarter also try to promote themselves as unique or artistic, though in fact they are ordinary shops selling mass-produced goods. In 2011 no less than 20 such shops selling jewellery, toys and souvenirs had the word 'gallery' in their name, some of them taking commercial advantage of the trend for ethno design and recycling art.

Hence, after a period of development, the progressing gentrification of Kazimierz, its growing real-estate prices and investment pressure seem to have led to stagnation or even a certain weakening and trivialisation of its culture-creating role in the context of the entire city. It is presently an area of commercial cultural consumption by the metropolitan class who spends its leisure time there, or a destination of tourist visits, rather than a hive of cultural creativity. Some cultural and artistic endeavours have moved from Kazimierz to other parts of the city. Others have become more commercially focused.

This rather pessimistic overview of the evolution of Kazimierz into a quarter of entertainment-oriented cultural consumption should, however, be broadened by remarks on three recently observed phenomena which may significantly modify or at least weaken the abovementioned negative trends. First, the stagnation or weakening of some institutions and cultural functions runs parallel to the establishment and development of others. The leading role in initiating urban regeneration and a rediscovery of Jewish culture in the quarter was once played by the Centre for Jewish Culture, an NGO independent from the Jewish community. Today it is not as visible because it has been overshadowed by two new, very dynamic institutions: the private Galicia Jewish Museum, which offers a broad cultural programme and promotes itself intensively, especially to tourists, and the Jewish Community Centre in Cracow, whose activities and services target mainly, though not exclusively, people who are Jewish or discovering their Jewish roots, and focus on contemporary issues of Jewish life rather than on the past. Hence, if a few years ago the production and consumption of Jewish culture in Kazimierz was often referred to as the creation of "virtual Jewishness" mainly by non-Jews for a nonJewish audience (Gruber 2002, Murzyn 2006), in the recent years the participation of the contemporary, rejuvenated and diversified Jewish community in rediscovering and redefining the Jewish character of the quarter has become increasingly visible (Murzyn-Kupisz 2012). In this way, by forging some continuity with pre-war traditions but at the same time not making them the main point of reference, Kazimierz may again become a quarter with a unique, ethnic character, a quarter not only of the Jewish past, but also of the Jewish present (Lehrer, forthcoming). The programme of the Jewish Cultural Festival and a number of other high-profile cultural initiatives linked with Jewish culture has evolved in a similar direction. 
The second positive change is the growing visibility and culture-creating role of public museums in Kazimierz, which generate a significant and rising share of museum attendance in Cracow (Table 2). Due to a systematic allocation of public resources, including EU funds, for the restoration of the historic complex of the $\mathrm{Mu}$ seum of Municipal Engineering, the regeneration of the entire tram depot is almost complete, which enables the museum to broaden the scope of its activities. In addition, the renovated inner 'courtyard' of the complex may now serve as an interesting venue for outdoor events. The Ethnographic Museum is also becoming more visible and active, especially since a new director took up his post in 2008, opening the facility wider to the audience and new trends in museum management and curatorship. It is presently one of the main anchor points in Cracow in the debate on the role of museums in contemporary society and inspirations that museums can offer creative industries, especially design (e.g. ethno design). It also willingly and increasingly frequently engages in other initiatives in the quarter, especially those linked with the Jewish heritage, approaching them in innovative ways.

The third trend is the above-mentioned new specialisation of Kazimierz as a quarter offering artistic workshops.

\section{Old Podgórze as an 'emerging' cultural quarter}

\subsection{Main characteristics of the quarter}

The area of Old Podgórze is located between the Vistula river and the Krzemionki hills south of historic Cracow and Kazimierz. ${ }^{4}$ Its diverse urban fabric consists of classicist houses, tenement houses, and villas set in their own gardens dating from the turn of the $19^{\text {th }}$ and $20^{\text {th }}$ centuries, but also housing blocks and infills from the post-war period, as well as numerous post-industrial buildings and complexes, most of them located in the post-industrial Zabłocie area. Despite its advantages over other historic districts

$4 \quad$ A former independent town, presently part of District XIII Cracow-Podgórze. of the city, such as relatively good accessibility, location, interesting landscape, and significant green leisure spaces, Podgórze is still perceived as a rather dangerous and less prestigious area, one of predominantly working-class character and industrial traditions where a Jewish ghetto was established by the Nazis during the Second World War. In the first years of the transformation period, with the exception of its main streets, it seemed to remain on the fringes of the changes taking place in Cracow. Since the turn of the new millennium, however, its popularity has increased significantly, initially with classic signs of gentrification (attracting artists and freelance professionals) and subsequently with the activities of developers, commercial gentrification and studentification (Murzyn-Kupisz, forthcoming). Activities which have developed dynamically in Podgórze in the recent years include tourism (hotels and catering), office functions (both adaptation of the existing housing stock and large, new investments), and luxury housing. The area has also attracted a major private higher education investment: the A.F. Modrzewski Cracow University has built its new campus there.

\subsection{Development of cultural and creative activities in the quarter after 1989}

The popularity of Podgórze, promoted by the media and developers as an 'emerging district' of Cracow (Cresswell 2008), has increased significantly in the recent years. In Podgórze there is a broad spectrum of artistic, entertainment, catering and avant-garde cultural activities. The wellknown contemporary art dealer Starmach was a pioneer in this process, restoring the former Jewish prayer house in Weggierska Street as a modern art gallery in the 1990s. An important role in both the initiation and monitoring of the process has been played by the Podgorze.pl Association. Functioning since 2002 as a web portal, in time it evolved into a very active NGO (2005) with its main aims being the promotion of the quarter and preservation of its unique landscape and traditions. It has published the first tourist guide to the area, and organises the annual Made in Podgórze Fair of Unique Things, at which local artists, craftspeople and small-scale producers 
present their products, and the Podgórze Open Monument Days. Its web page provides up-todate information on interesting events, especially cultural ones, as well as problems encountered in the quarter. Over the last few years Podgórze has also started to attract artistic cafés, restaurants and galleries, some of them moving from other quarters and/or occupying post-industrial spaces. The cellars and ground floor of a tenement house in Nadwiślańska Street near the new pedestrian bridge, for instance, have become the new premises of the Drukarnia club. The former Miraculum cosmetics factory complex has attracted diverse artistic activities. It is ultimately to be demolished to make room for new buildings, but in the interim over the past two years night life, artistic presentations and events as well as smallscale creative ventures have successfully coexisted there (e.g. small firms such as the galleries Kathedra and Atropos, and the Atropos publishing house). Its focal point was Fabryka (The Factory), an art club founded in 2010 and until mid-2011 offering a broad cultural programme, run by the owners of the well-known Alchemia of Kazimierz. Another interesting initiative in the former factory complex was Zbiornik Kultury (the Culture Tank): a gallery - exhibition space artistic centre active in Zabłocie for a few months in 2010 and then again for a few months in 2011. Run thanks to the enthusiasm of young artists who managed to obtain a modest public grant, the Culture Tank fitted well with the spontaneous grouping of artists and creative activities. In the context of the entire city, Podgórze has also started to play a more significant role as a place of artistic education, not only at the elementary and secondary levels (three music schools), but also at the post-secondary level, with new private schools. Two buildings (in Dekerta and Zamojskiego Streets) have been renovated to house the Cracow School of Art and Fashion Design, which offers courses in fashion design, interior design, creative photography, visual merchandising, and drama. The A.F. Modrzewski University offers degrees in interior design, architecture and urban planning, journalism and communication, cultural studies, painting, and television and film production. It also runs post-graduate courses in journalism and media, and the art and antiques market. Its students have the use of two profes- sionally equipped television studios. It should also be mentioned that the headquarters of the Cracow branch of Polish public television (TVP) are located in Podgórze, which means that the quarter has for years been associated with television production.

In the last few years, apart from the spontaneous changes described above, there has also been deliberate action by public authorities to promote Podgórze as a cultural quarter, primarily through the development of supra-local cultural functions and, to a lesser extent, reconstruction of public spaces. In 2010 the adaptation of part of the former Emalia Factory in Lipowa Street (the "Schindler Factory") was completed. It now houses a new branch of the Historical Museum of the City of Cracow focused on the research on and presentation of Cracow's history during the Second World War. Its main exhibition, showing in a very innovative and thought-provoking way the fate of Cracow and its residents, with special focus on the Holocaust and suffering of the Jewish community during the war, has received much praise and attracted a lot of interest. It attracted 111,000 visitors in the first year it opened to the general public (the latter six months of 2010), and almost 200,000 in 2011. This translates into a daily average of over 500 guests (Table 2). The remaining part of the postindustrial complex in Lipowa Street has been re-

Table 2. Visitors to public museums in Kazimierz and Podgórze in 2010.

\begin{tabular}{|l|c|}
\hline \multicolumn{1}{|c|}{ Museum } & Attendance \\
\hline Ethnographic Museum & 44,500 \\
\hline Old Synagogue & 101,402 \\
\hline Museum of Municipal Engineering & 112,799 \\
\hline Total attendance in Kazimierz & 258,701 \\
\hline Eagle Pharmacy & 56,149 \\
\hline Schindler's Factory (since June 2010) & 111,428 \\
\hline $\begin{array}{l}\text { Museum of Contemporary Art (since } \\
\text { Nov. 2010) }\end{array}$ & 15,958 \\
\hline Total attendance in Podgórze & 183,535 \\
\hline $\begin{array}{l}\text { Share of museums located in Kazi- } \\
\text { mierz in overall museum attendance } \\
\text { in Cracow (\%) }\end{array}$ & 8.22 \\
\hline $\begin{array}{l}\text { Share of museums located in } \\
\text { Podgórze in overall museum attend- } \\
\text { ance in Cracow (\%) }\end{array}$ & 5.83 \\
\hline
\end{tabular}

Source: own elaboration based on data obtained from the Historical Museum of the City of Cracow and Raport ... (2011). 
developed as the Museum of Contemporary Art in Cracow (MOCAK). In the first two months of its operation (at the end of 2010) it welcomed almost 16,000 visitors. Another major public investment, the enlargement and adaptation of the historic municipal power house in Nadwiślańska Street into the Museum of Tadeusz Kantor, an avant-garde architectural project by the regional authorities, is currently underway. In addition, the municipal Podgórze Cultural Centre recently took over a monumental historic building in Legionów Piłsudskiego Street as its main seat. The future function of the historic St Benedict's Inn in Wielicka Street is under discussion. Initially there were plans to locate a museum of the Podgórze history there. At present the city authorities are considering the possibility of using the building for a museum dedicated to the art of one of the best-known Polish post-war painters, Jerzy Duda-Gracz. Another historic building owned by the municipality is the former salt warehouse in Na Zjeździe Street. Again, the first idea, to establish a local history museum there, was soon replaced by a proposal to adapt it for use as the seat of a prestigious classical music institution. In the summer of 2012 yet another new idea arose: to transform it into a Literature House - a centre promoting Polish literature, the achievements of Nobel Prize winners in the field of literature, and the work of other writers linked with Cracow. Although the proposal to reconstruct and extend the historic St Benedict's Fort for cultural purposes put forward by a nonlocally based NGO in cooperation with the city provoked strong protests from local residents, conservators and NGOs and was ultimately abandoned, in the future we may expect further new attempts at introducing a cultural function to this complex too.

Recent public investments in the quarter's public spacesinclude therenovation of Niepodległości (Independence) Square near Kalwaryjska Street and the remodelling of Bohaterów Getta (Heroes of the Ghetto) Square coupled with its conversion into a Holocaust memorial site, completed in 2005. In 2010 the already mentioned Bernatka Bridge between Kazimierz and Podgórze was completed. A pedestrian and bicycle bridge was also built between two historic areas of Podgórze - Krzemionki Hill and Krakus Mound.
In terms of activities that can be referred to as creative, a grouping of printing houses and satellite firms is visible in Zabłocie (11 firms of this type) (Table 1). In Podgórze, again mainly in the Zabłocie area, there are also numerous advertising and promotion design and production firms. Small editorial offices and publishing houses in Podgórze are more dispersed across the quarter. The fairly numerous architectural offices and studios (15) are usually small and do not include any better known firms. There are only single firms in the fashion, furniture or computer game design sectors. There are quite a number of antiques shops, but again no prestigious, better known establishments among them. Equally numerous are artistic craft workshops, which are mostly traditional in profile (bronze, ceramics, engraving, stained glass). As in Kazimierz, art, theatre and dance workshops are organised in several places in Podgórze. Although there are as yet no permanent theatres in Podgórze, three small theatre groups are based in the area. The Scene in the John Paul II Quarry next to St Joseph's Parish Church functions as a venue for performances and concerts, as does the recently opened small private theatre venue in a post-industrial building in Lwowska Street. As this overview shows, Podgórze has evolved into a cultural quarter both through public action and private endeavours, and is less a centre of entertainment and nightlife related consumption than a place of cultural education, creativity and presentation. This is reflected in the fact that in 2011 the ratio of catering outlets to creative establishments in Podgórze was 1:3.5.

\subsection{Challenges faced by Podgórze as a cultural quarter}

Many of the private cultural activities and initiatives in Podgórze are, however, ephemeral. As Zabłocie and other parts of Podgórze fill with new apartment and office buildings, it will become increasingly difficult to develop or even maintain the existing creative functions of Podgórze. In October 2011 Arsharter - Atelier Hothaus, an artistic group and organiser of workshops and events, mainly in the field of theatre, based since the autumn of 2009 in the former Telpod facto- 
ry building in Romanowicza Street, moved out of the quarter. The artistic cluster in the former Miraculum factory also seems to be losing momentum, mainly due to the uncertainty about the site's future and rising costs of its operation. In June 2011 an 'official funeral' of the Factory was held. In November 2011 the club was reactivated, but with a less broad and ambitious programme. Artists say that the positive creative impulses visible in Zabłocie in the recent years are becoming weaker, mainly due to the domination of the quarter's regeneration by commercial actors and lack of sufficient support from the city authorities, including major municipal cultural institutions, for whom creating synergies between public and private cultural ventures should be an important responsibility. Such an attitude on the part of the public authorities is even harder to understand, since their allocation of significant financial resources to costly flagship projects seemed to indicate an understanding of the quarter's cultural potential. According to Okoński, artistic manager of both editions of the Culture Tank, "The developers have not backed off; they are not interested in the fact that Zabłocie has developed some symbolic capital, already created a certain artistic brand. We cannot afford to stay there. The regeneration of the quarter is in this sense a mission of MOCAK and Schindler's Factory, institutions which are large enough to support such processes" (Białkowski 2011).

\section{Final remarks}

Unique clusters or groupings of activities linked with culture, creativity and leisure often form, or are designated within, larger urban centres with well developed higher-rank functions. Interesting, visible areas of this type have emerged in Cracow after 1989. The historic district of Kazimierz was the first to acquire some features of a cultural quarter, mainly due to spontaneous activities of artists and private entrepreneurs. In the recent years Old Podgórze and its post-industrial area of Zabłocie have been regarded as a promising cultural quarter, attracting artists, creative-sector entrepreneurs, and significant public investments. Practically unknown on the tourist map of Cracow in the early 1990s, over time both quarters have become significant tourist attractions and areas frequently visited by museum goers. Kazimierz is presently considered the second most important tourist attraction in Cracow after the sites and attractions in the city core. Even prior to the opening of its two major museums, Podgórze began to be

Table 3. Top 15 tourist attractions in the opinion of visitors to Cracow in 2008 and 2009.

\begin{tabular}{|l|r|r|r|r|c|c|}
\hline \multirow{2}{*}{ Tourist attractions } & \multicolumn{2}{c|}{$\begin{array}{c}\text { Domestic } \\
\text { visitors (\%) }\end{array}$} & \multicolumn{2}{c|}{$\begin{array}{c}\text { Foreign visitors } \\
\text { (\%) }\end{array}$} & \multicolumn{2}{c|}{ Rank } \\
\cline { 2 - 6 } & $\mathbf{2 0 0 8}$ & $\mathbf{2 0 0 9}$ & $\mathbf{2 0 0 8}$ & $\mathbf{2 0 0 9}$ & $\mathbf{2 0 0 8}$ & $\mathbf{2 0 0 9}$ \\
\hline Main Square (Old Town, Royal Way) & 50.1 & 66.1 & 52.9 & 65.4 & 1 & 1 \\
\hline Wawel (hill, castle and cathedral) & 41.7 & 58.2 & 52.6 & 57.6 & 2 & 2 \\
\hline Kazimierz (synagogues, cafés, concerts, etc.) & 14.1 & 24.8 & 31.4 & 39.0 & 3 & 3 \\
\hline St Mary's Church (including Veit Stoss altar) & 10.1 & 12.6 & 15.1 & 13.7 & 4 & 4 \\
\hline Cloth Hall & 10.1 & 11.0 & 7.5 & 12.1 & 6 & 5 \\
\hline Nowa Huta (Central Square, socialist realism trail, etc.) & 8.0 & 7.6 & 6.4 & 6.8 & 7 & 6 \\
\hline Sanctuary of Divine Mercy in Łagiewniki & 12.4 & 7.6 & 8.6 & 5.6 & 5 & 7 \\
\hline Barbican (including Florian Gate) & 7.5 & 6.8 & 4.5 & 5.6 & 8 & 8 \\
\hline Galeria Krakowska (shopping centre) & 6.8 & 6.1 & 1.5 & 0.8 & 10 & 9 \\
\hline Czartoryski Museum & 1.7 & 2.7 & 4.7 & 4.8 & 12 & 10 \\
\hline Benedictine Abbey in Tyniec & 7.5 & 3.6 & 3.5 & 3.1 & 9 & 11 \\
\hline Vistula boulevards & 4.1 & 4.2 & 2.0 & 1.9 & 11 & 12 \\
\hline Wolski Forest (including municipal zoo) & $-*$ & 2.0 & - & 1.1 & - & 13 \\
\hline National Museum (including Erasmus Ciołek Palace) & 1.3 & 2.5 & 1.7 & 1.9 & 20 & 14 \\
\hline Kościuszko Mound & 2.8 & 2.4 & 2.0 & 1.1 & 15 & 15 \\
\hline Podgórze & - & 2.4 & - & 1.1 & - & 15 \\
\hline
\end{tabular}

* not mentioned or ranked lower than 20th in the 2008 survey.

Source: Borkowski et al. (2009: 129). 
mentioned as another significant attraction of Cracow (Table 3).

Given the tendencies observed in both districts in the context of the desired features discussed above, and the conditions and success factors of cultural quarters (Table 4), although both Kazimierz and Podgórze possess many characteristics of cultural quarters, the current evolution of their activities, functions, urban space and built forms makes further development of their cultural quarter status rather uncertain and problematic. In the future, the progressive commercialisation of both districts may lead to a significant weakening or even disappearance of their culture-creating role for the city. For example, catering and entertainment-oriented activities already dominate in the image and functions of Kazimierz, leading to its perception primarily as a night-life and entertainment quarter rather than one inspiring cultural and creative activities. In Podgórze, catering establishments do not yet clash with other functions, including creative activities. However,

Table 4. Tendencies observed in the transformation of Kazimierz and Podgórze in 2011.

\begin{tabular}{|c|c|c|}
\hline & Major tendencies in Kazimierz & Major tendencies in Podgórze \\
\hline \multicolumn{3}{|c|}{ Functions and activities } \\
\hline $\begin{array}{l}\text { Public cultural } \\
\text { institutions, major } \\
\text { cultural events }\end{array}$ & $\begin{array}{l}\text { - Recently completed regeneration of tram } \\
\text { depot area for cultural purposes } \\
\text { - Main setting for major cultural event (Jew- } \\
\text { ish Culture Festival) }\end{array}$ & $\begin{array}{l}\text { - Recent introduction of prestigious exog- } \\
\text { enous cultural functions (two new mu- } \\
\text { seums, one museum under construction, } \\
\text { other institutions under consideration) }\end{array}$ \\
\hline $\begin{array}{l}\text { Smaller-scale private } \\
\text { and non-govern- } \\
\text { mental cultural and } \\
\text { creative ventures }\end{array}$ & $\begin{array}{l}\text { - Declining number of art galleries, new type } \\
\text { of artistic shops with both mass-produced } \\
\text { and hand-made objects } \\
\text { - Constant number of small private theatres } \\
\text { - Increasing number of small private venues } \\
\text { offering artistic workshops and courses }\end{array}$ & $\begin{array}{l}\text { - Numerous activities of artistic avant-garde } \\
\text { and small-scale artistic projects } \\
\text { - Cluster of smaller-scale printing and pub- } \\
\text { lishing activities } \\
\text { - Active locally based NGO strongly embed- } \\
\text { ded in local context }\end{array}$ \\
\hline $\begin{array}{l}\text { Evolution of cultural } \\
\text { offer }\end{array}$ & $\begin{array}{l}\text { - Trivialisation and touristification of artistic } \\
\text { offer } \\
\text { - High real-estate prices and commercialisa- } \\
\text { tion pressure not conducive to maintenance } \\
\text { of smaller-scale artistic and creative activi- } \\
\text { ties }\end{array}$ & $\begin{array}{l}\text { - Broadening of cultural offer due to activi- } \\
\text { ties of new major public actors } \\
\text { - Activities of artistic avant-garde and small- } \\
\text { scale projects visible and developing but in } \\
\text { danger of disappearance due to investment } \\
\text { pressure of non-cultural commercial actors }\end{array}$ \\
\hline Leisure & $\begin{array}{l}\text { - For over a decade generally considered at- } \\
\text { tractive for gazing, sitting and wandering }\end{array}$ & $\begin{array}{l}\text { - Selected areas (e.g. near new pedestrian } \\
\text { bridge) considered attractive for sitting and } \\
\text { gazing } \\
\text { - Historic green areas as local leisure sites }\end{array}$ \\
\hline $\begin{array}{l}\text { Night life and enter- } \\
\text { tainment }\end{array}$ & $\begin{array}{l}\text { - Rising number of non-artistic catering } \\
\text { establishments, their rate of growth more } \\
\text { dynamic than that of cultural and creative } \\
\text { activities }\end{array}$ & $\begin{array}{l}\text { - Rising importance of the quarter as night- } \\
\text { life and entertainment area }\end{array}$ \\
\hline Tourism & $\begin{array}{l}\text { - Rising number of establishments offering } \\
\text { tourist accommodation, rising importance } \\
\text { of tourist function }\end{array}$ & $\begin{array}{l}\text { - Rising importance on tourist map of Cra- } \\
\text { cow }\end{array}$ \\
\hline $\begin{array}{l}\text { Artistic and creative } \\
\text { education }\end{array}$ & $\begin{array}{l}\text { - Increasing number of private firms offer- } \\
\text { ing amateur artistic instruction to general } \\
\text { public }\end{array}$ & $\begin{array}{l}\text { - Institutions offering professional education } \\
\text { in artistic and creative fields }\end{array}$ \\
\hline Housing & $\begin{array}{l}\text { - Progressive loss of regular residential } \\
\text { function, temporary residents (tourists, } \\
\text { students, young adults) } \\
\text { - Very high real-estate prices }\end{array}$ & $\begin{array}{l}\text { - Rising share of temporary residents } \\
\text { - New, luxury residential function in post- } \\
\text { industrial area of Zabłocie (mainly financial } \\
\text { gentrification) } \\
\text { - Very high real-estate prices }\end{array}$ \\
\hline Other & $\begin{array}{l}\text { - Focal point for redefinition of contempo- } \\
\text { rary Jewish community and its activities } \\
\text { - Focal point for research and cultural activi- } \\
\text { ties linked to Jewish and Israeli culture and } \\
\text { heritage } \\
\text { - Informal networks and links between vari- } \\
\text { ous actors }\end{array}$ & $\begin{array}{l}\text { - Rising importance of non-cultural func- } \\
\text { tions: up-scale housing, offices, tourist } \\
\text { accommodation }\end{array}$ \\
\hline
\end{tabular}


Table 4. cont.

\begin{tabular}{|c|c|c|}
\hline & Major tendencies in Kazimierz & Major tendencies in Podgórze \\
\hline \multicolumn{3}{|c|}{ Urban space and built form } \\
\hline Built fabric & $\begin{array}{l}\text { - Some new construction but mainly reno- } \\
\text { vation of building stock for commercial, } \\
\text { non-culturally oriented purposes (tourist } \\
\text { accommodation, financial gentrification), } \\
\text { at times detrimental to quarter's historic } \\
\text { ambiance }\end{array}$ & $\begin{array}{l}\text { - Renovation of built fabric for commercial, } \\
\text { non-culturally oriented purposes } \\
\text { - Numerous new building projects of com- } \\
\text { mercial and exclusive character (apartment } \\
\text { complexes, offices), inward oriented and } \\
\text { without significant architectural value }\end{array}$ \\
\hline $\begin{array}{l}\text { Buildings and sites } \\
\text { with cultural func- } \\
\text { tion }\end{array}$ & $\begin{array}{l}\text { - Regeneration of unique tram depot area } \\
\text { - New Jewish Community Centre building }\end{array}$ & $\begin{array}{l}\text { - New and redeveloped buildings of major } \\
\text { cultural institutions }\end{array}$ \\
\hline Public spaces & $\begin{array}{l}\text { - No major public projects focused on re- } \\
\text { newal of public spaces } \\
\text { - Smaller-scale, to some extent spontaneous } \\
\text { changes to parts of quarter's public space } \\
\text { by private actors }\end{array}$ & $\begin{array}{l}\text { - Renewal of selected public spaces and } \\
\text { enhancement of their meaning (Heroes of } \\
\text { Ghetto Square); at the same time neglect of } \\
\text { others }\end{array}$ \\
\hline Links to other areas & \multicolumn{2}{|c|}{ - Construction of pedestrian bridge linking two quarters } \\
\hline \multicolumn{3}{|c|}{ Symbolic meaning } \\
\hline Linked to past & $\begin{array}{l}\text { - Jewish quarter of Cracow, site of Jewish } \\
\text { presence and absence }\end{array}$ & - Site of World War II ghetto \\
\hline $\begin{array}{l}\text { Linked to quarter's } \\
\text { transformation }\end{array}$ & $\begin{array}{l}\text { - Recently regenerated, former problem area } \\
\text { of Cracow }\end{array}$ & $\begin{array}{l}\text { - Rather degraded but promising inner city } \\
\text { and post-industrial quarter undergoing } \\
\text { commercial revitalisation }\end{array}$ \\
\hline Linked to culture & - Bohemian and night-life quarter & - Promising bohemian area \\
\hline
\end{tabular}

Source: own elaboration based on the features, conditions and success factors of cultural quarters proposed by Montgomery (2003) and Moss (2002).

its advancing gentrification coupled with lack of support on the part of the city authorities, which should be trying to foster synergies between major cultural investments and creative activities in the area (e.g. by establishing an effective "public creative intermediary", Evans 2004), can lead to an undesirable imbalance between creative and other activities. Rather than a real cultural quarter, then, Podgórze may thus become a well located but indistinguishable area consisting of enclaves of luxury housing complexes and office buildings. Even if major museums are present in the quarter, they will not be institutions inspiring smaller-scale creative activities in their vicinity, but only sites of tourist consumption. ${ }^{5}$ Without

5 A very recent project (August 2012) initiated by a public actor that can be considered a positive though modest step in the further development of the cultural function of Podgórze is the opening of a Glass and Ceramics Gallery near the MOCAK museum in Lipowa Street as a first step towards the creation of the Centre of Glass and Ceramics comprising a gallery and an exhibition of historic and modern artistic glass, as well as running workshops on hand-made glass and conducting research on glass used in monument conservation as part of the Cracow branch of the Institute of Ceramics and Building Materials. drawing on the earlier experiences of their West European counterparts (e.g. Evans 2004, Miles 2004), the two quarters will replicate previously criticised development paths, being unable to avoid significant negative developments and sustainability problems. If the process of change in both districts does follow this negative scenario, a great opportunity to develop distinct functional areas which could significantly strengthen the role of culture as an important contemporary metropolitan function of Cracow will most likely be lost.

\section{References}

BIAŁKOWSKI Ł., 2011. Zbiornik Kultury. DIY po krakowsku (Culture Tank. DIY the Cracow way). Obieg, 1 September.

BiANCHINI F. \& PARKINSON M. (eds), 1993. Culture and urban regeneration: The West European experience. Manchester University Press, Manchester.

Big Städtebau GmbH, 2008. Miejski Program Rewitalizacji Krakowa (Urban regeneration programme for Cracow). Urząd Miasta Krakowa, Kraków.

Bell D. \& Jayne M., 2004. Conceptualising the city of quarters. In: Bell D. \& Jayne M. (eds), City of quarters. Urban villages in the contemporary city. Ashgate, Aldershot: 1-12. 
Borkowski K., Grabiński T., Mazanek L., Seweryn R. \& WilkońskA A., 2009, Badanie ruchu turystycznego w Krakowie w 2009 roku (Research on tourism traffic in Cracow in 2009). MOT, Kraków.

Cresswell P., 2008. Streets ahead series. The Guardian, 18 October.

De Propris L. \& WeI P., 2009. Creativity and space: The opportunity of an urban creative jewellery cluster. Creative Industries Journal, 1: 37-56.

EvANs G., 2004. Cultural industry quarters: From pre-industrial to post-industrial production. In: Bell D. \& Jayne M. (eds), City of quarters. Urban villages in the contemporary city. Ashgate, Aldershot: 71-92.

FLEMING T., 2004. Supporting the cultural quarter? The role of the creative intermediary. In: Bell D. \& Jayne M. (eds), City of quarters. Urban villages in the contemporary city. Ashgate, Aldershot: 93-108.

GrochowsKi M., 2010. The creative sector in Warsaw. The city's potential and development conditions. In: Jeziorek P., Le Nart A., Petrul E. \& Świątkowska B. (eds), Creative people. Creative living in Warsaw. Guide to Warsaw's creative sector. City of Warsaw, Warszawa.

Gruber R.E., 2002. Virtually Jewish: Reinventing Jewish culture in Europe. University of California Press, Berkeley and Los Angeles.

KLASIK A. (ed.), 2011. The cities and agglomerations development based on the culture sector and creative industries. Polish Academy of Sciences, Warsaw.

LEHRER E., forthcoming. Jewish Poland revisited: Heritage tourism in unquiet places. Indiana University Press, Bloomington.

MAZiareK S. \& HAJOK D., 2011. Znikną galerie z ul. Józefa, wyprowadzą się mieszkańcy (Galleries will disappear, residents will move out of Józefa Street). Gazeta Wyborcza Kraków, 16 August.

Miles M., 2004, Drawn and quartered: El Raval and the Haussmannization of Barcelona. In: Bell D. \& Jayne M. (eds), City of quarters. Urban villages in the contemporary city. Ashgate, Aldershot: 37-55.
Montgomery J., 2003. Cultural quarters as mechanisms for urban regeneration. Conceptualizing cultural quarters. Planning, Practice and Research, 4: 293-306.

Moss L., 2002. Sheffield's cultural industries quarter 20 years on: What can be learned from a pioneering example? The International Journal of Cultural Policy, 2: 211-219.

Murzyn M., 2006. Kazimierz. The Central European experience of urban regeneration. ICC, Kraków.

Murzyn-Kupisz M., 2012. From "Atlantis" to ...? The past and present of Jewish Cracow in the second decade of the new millennium. Conference materials. The European Association for Urban History 11th International Conference on Urban History: Cities $\mathcal{E}$ societies in comparative perspective, Charles University, Prague.

Murzyn-KupIsz M., forthcoming. Przemiany historycznych dzielnic śródmiejskich w dobie neoliberalnego urbanizmu. Przykład Starego Podgórza w Krakowie (Changes in historic inner-city quarters in times of neoliberal urbanism. The case of Old Podgórze in Cracow). In: Sagan I. \& Szmytkowska M. (eds), Miasto w dobie neoliberalnego urbanizmu. Uniwersytet Gdański, Gdańsk.

Musterd S. \& Murie A. (eds), 2010. Making competitive cities. Wiley-Blackwell, Oxford.

O'CONNOR J., 2004. A special kind of city knowledge: Innovative clusters, tacit knowledge and the 'Creative City'. Media International Australia, 112: 131-149.

Raport o stanie miasta $w 2010$ r. (Report on the city for 2010), 2011. Urząd Miasta Krakowa, Kraków.

Roodhouse S. (ed.), 2010. Cultural quarters. Principles and practice. Intellect, Bristol-Chicago.

Roodhouse S., Mokre M., 2004. The MuseumsQuartier Vienna: An Austrian cultural experiment. International Journal of Heritage Studies, 2: 193-207.

SACCO P.L., 2010. The cultural economics of quarters. In: Roodhouse S. (ed.), Cultural quarters. Principles and practice. Intellect, Bristol-Chicago: 29-46.

Stryjakiewicz T., Kaczmarek T., Męczyński M., Parysek J.J. \& Stachowiak K., 2007. Poznań faces the future. Pathways to creative and knowledge-based regions. AMIDSt, Amsterdam. 